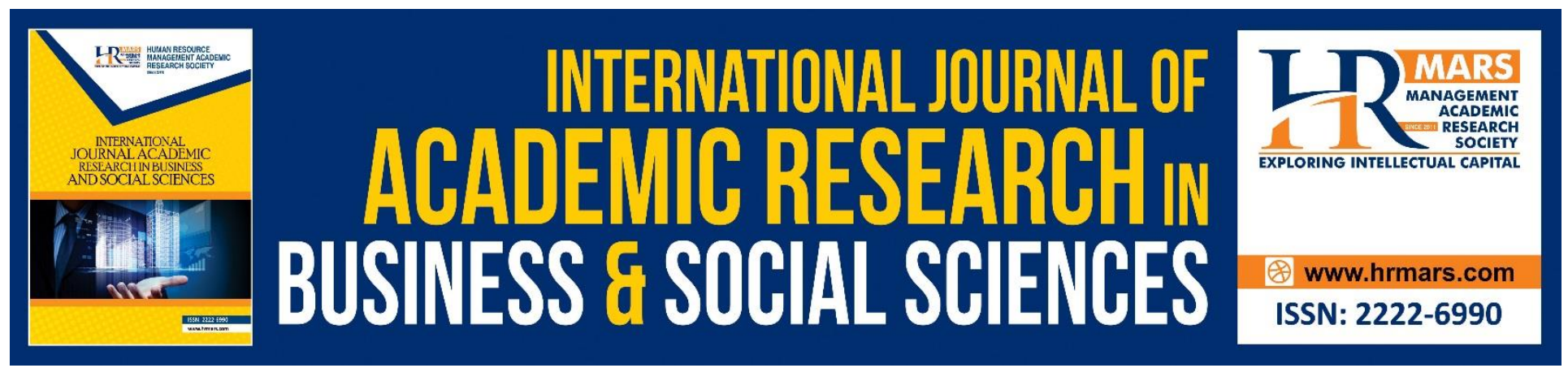

\title{
Psychological Factor (Mental Model) That Influencing the Usage of Fishery Technology Among Youth Fishermens: A Narrative Review
}

Norsida Man, Nurul Farhana Saharrudin, Asnarulkhadi Abu Samah, Nobaya Ahmad \& Samsul Farid Samsuddin

To Link this Article: http://dx.doi.org/10.6007/IJARBSS/v11-i15/10647

DOI:10.6007/IJARBSS/v11-i15/10647

Received: 16 May 2021, Revised: 20 June 2021, Accepted: 08 July 2021

Published Online: 26 July 2021

In-Text Citation: (Man et al., 2021)

To Cite this Article: Man, N., Saharrudin, N. F., Samah, A. A., Ahmad, N., \& Samsuddin, S. F. (2021). Psychological Factor (Mental Model) That Influencing the Usage of Fishery Technology Among Youth Fishermens: A Narrative Review. International Journal of Academic Research in Business and Social Sciences, 11(15), 206213.

\section{Copyright: (C) 2021 The Author(s)}

Published by Human Resource Management Academic Research Society (www.hrmars.com)

This article is published under the Creative Commons Attribution (CC BY 4.0) license. Anyone may reproduce, distribute, translate and create derivative works of this article (for both commercial and non-commercial purposes), subject to full attribution to the original publication and authors. The full terms of this license may be seen

at: http://creativecommons.org/licences/by/4.0/legalcode

Special Issue: Empowering Youth and Community Wellbeing for Sustainable Development, 2021, Pg. 206 - 213 http://hrmars.com/index.php/pages/detail/IJARBSS JOURNAL HOMEPAGE

Full Terms \& Conditions of access and use can be found at http://hrmars.com/index.php/pages/detail/publication-ethics 


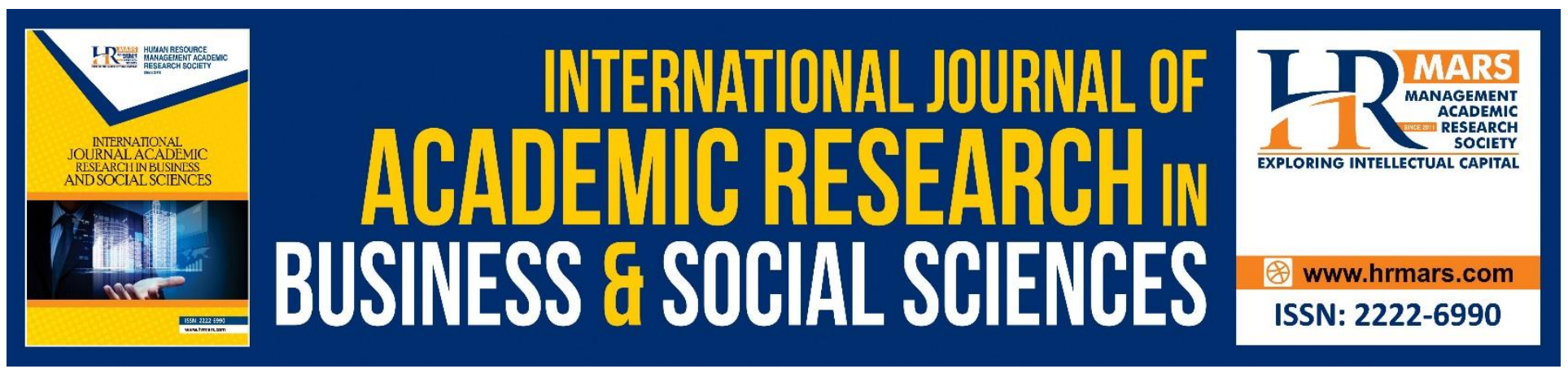

\title{
Psychological Factor (Mental Model) That Influencing the Usage of Fishery Technology Among Youth Fishermens: A Narrative Review
}

\section{Norsida Man ${ }^{1}$, Nurul Farhana Saharrudin², Asnarulkhadi Abu Samah $^{2,3}$, Nobaya Ahmad ${ }^{3}$ \& Samsul Farid Samsuddin ${ }^{4}$}

${ }^{1}$ Faculty of Agriculture, Universiti Putra Malaysia, 43400 Serdang, Selangor, Malaysia, ${ }^{2}$ Institute for Social Science Studies, Universiti Putra Malaysia, Putra, 43400 Serdang, Selangor, Malaysia, ${ }^{3}$ Faculty of Human Ecology, Universiti Putra Malaysia, 43400 Serdang, Selangor, Malaysia, ${ }^{4}$ Faculty Computer

Science and Information Technology, University Malaya, 50603 Kuala Lumpur, Malaysia

Email: norsida@upm.edu.my

\begin{abstract}
The mental model is a psychological factor that can influence the decision-making process. This is a narrative review article and its main objective is to examine potential factors that influence the mental model (decision-making process) of youth fishermen on the use of fisheries technology. Understandably, the youth fishermen face two crucial problems, namely poverty and climate change, and the Malaysian government has launched a range of fisheries innovations such as GPS, echo sounders, and wireless sets to assist them in facing these two issues. Fishing technologies are beneficial, and past studies have shown that use of fisheries technology is very beneficial to the youth fishermen in terms of increasing their income and lessen the risks associated with climate change impacts. In conclusion, mental model will influence the decision-making process of youth fishermen whether to adopt the technology or not. Factors such as experience, knowledge, expertise and belief may have an impact on the fishermen's mental model.
\end{abstract}

Keyword: Mental Model, Psychology, Youth Coastal Fisherman, Fishery Technology

\section{Introduction}

The fisheries sector has played a significant role in improving both the countries' economies and the communities socio-economic. Instead of having more than 120,000 registered fishermen in Malaysia (Department of Fishery Malaysia, 2019), the exact number of youth fishermen in Malaysia is still unclear. There are several common characteristics of youth fishermen. Their age for example are defined as those whose aged between 15 and 40 years of age and this group is estimated to represent maximum of 35 per cent of the total fishing population in this country (Shaffril et al., 2015; Shaffril et al., 2017; Muhammad et al., 2018). This figure demonstrates the need for more involvement from the younger generation as a response to the issue related to aging fishing community. The youth 
fishermen will ensure that the industry receives adequate backup from the younger generation, thus enhancing the security of food supply in the nation.

The rising number of fishermen has had a huge impact on Malaysia's marine catch where land revenue in 2016 exceeded RM10.2 million. However, this huge amount is seen to benefit deep-sea fishermen (Zone B, Zone C2 and Zone $\mathrm{C} 0$ ) and not fishermen (coastal fishermen) from Zone A. According to studies conducted by Omar et al (2012); Shaffril et al (2013); Shaffril et al (2014), most coastal fishermen can be categorized as a poor group. Things are made worse by climate change, which affects weather elements such as waves, winds, rain cycles and the north-eastern monsoon (Azli, 2010; Subramaniam et al 2010; Razali et al 2010; Suhaila et al 2010; Tanggang, 2007). Realizing these two (2) keys problems - hunger and climate change, the Malaysian government has introduced many initiatives to assist young fishermen through the implementation of fishery technologies such as GPS (to move fishermen accurately into the catchment area), echo sounder (to locate fish groups) and cell phones (for contact and emergency purposes).

The implementation of these fishing technologies is expected to benefit the youth fishermen, as they are seen as a technology savvy user and are eager to use fisheries technology (Osman et al. 2014). Studies conducted by Musa et al (2011) and Osman et al. (2014), they have shown that the use of technologies such as GPS, echo sounder and mobile phones can help fishermen to identify fish locations, to find fish groups, to make travel easier, to facilitate bilateral communication with fishermen, family members and agency officials, and to increase their level of safety while carrying out their daily routine. Based on Musa et al (2011); Bolong et al (2012), it can be seen that fisheries technology has increased revenue, saved fishermen's time, expanded their markets and facilitated communication, especially in the event of an emergency.

The benefits of these fishing technologies have attracted more fishermen, particularly the younger group, to use fishery technology (Osman et al., 2014). Drawing on Omar et al (2012); Shaffril et al (2014), over 95\% of fishermen use mobile phones, $29 \%$ use GPS and $20 \%$ use echo sounder in their fishing operation. The situation has posed one key question, what are the factors affecting their decision in the use of fisheries technologies and one way to address this is by looking at it from the viewpoint of the mental model (Hamzah et al., 2013). Mental model can be described as a process of clarifying someone thinks about how things are done. It encompasses the role of a person's beliefs, skills and experience in processing information using existing skills to learn something new or solve problems. In addition, mental models can help to shape behavior and set an approach to solving problems in performing tasks.

\section{Technology Usage in Fishing}

Different authors define technology in different ways. According to Loevinsohn et al (2013) technology is the means and methods of producing goods and services, including methods of organization as well as physical technique. Technology itself is aimed at improving a given status quo to a more desirable level. It assists the applicant to do work effectively and efficiently than he/she would have done in the absence of the technology (Bonabana-Wabbi, 2002).

A new agricultural technology that enhances sustainable production of food is therefore critical for sustainable food security and economic development. This has made the dynamics of technical 
change in agriculture to be an area of intense research since the early part of twentieth century (Jain et al., 2009).

While, technology adoption has played a key role in the global development and increase in agricultural productivity. However, the decision to adopt a new technology on farms is complex. According to Loevinsohn et al (2013), a farmer's decisions about whether and how to adopt new technology are conditioned by the dynamic interaction between characteristics of the technology and the array of conditions and circumstances. Diffusion itself results from a series of individual decisions to begin using the new technology, decisions which are often the result of a comparison of the uncertain benefits of the new invention with the uncertain costs of adopting it (Hall and Khan, 2002).

For fishery technology, it consists of the equipment and practices used for finding, harvesting, handling, processing and distributing of aquatic resources and their products. Different fishery technologies will have different effects on the ecosystem, the social structure of fishing communities, the safety of fishery workers and the ease, effectiveness and efficiency of management of the fishery (FAO, 1996).

Fishermen using traditional methods depend on luck and indigenous knowledge compared to those using advanced technologies. Having old ways of doing things, traditional fishermen are forced to spend more time, energy and money on finding and re-detecting new fishing grounds. Things are completely different for modern fishermen, as they enjoy a number of advantages offered by fishing technologies. Based on a study conducted by Omar et al (2012) most local fishermen use a simple device in their fishing routine, such as mobile phones, compared to advance fishing tools, for example. However, an increasing number of those who embrace new and advanced fishing technologies such as GPS, sonar, wireless and remote sensing are expected to result in more fishermen receiving more catch and income, shorter fishing operations and reduced risks (Abu Hassan et al., 2011; Shaffril, 2021).

Studies conducted by Omar et al. (2012) and Bolong et al. (2012) have shown a significant positive relationship between the income of fishermen and the use of modern technology. This finding is supported by Ghee Thean et al. (2012) who claimed that the use of the echo sounder was positively associated with the catch and efficiency of the fishermen.

\section{Mental Model}

Issues related to the mental model and the use of technology have attracted a number of scholars across the globe. In a study conducted by Azimi et al (2013), the focus was on fishermen's mental model of advanced technology use among fishermen. They emphasized the importance of fishermen using fishing technologies such as GPS, echo sounder and wireless to combat poverty and overcome the risks of climate change. Factors such as experience, knowledge, expertise and belief may have an impact on the fishermen's mental model.

In another study conducted by Eckert and Bell (2005), mental model is mechanism for perceived information and experience in decision-making in a situation of variety. It screens the roles and importance of experience, beliefs, knowledge, skills and methods in the process of problem-solving 
learning information. In a study by Krauss et al. (2009), in order to be successful, the farmer needs to cross borders in a mental model that keeps them in line with conventional farming methods and blocks them in order to achieve better success.

Seel (2001) concluded that the mental model is rarely labeled as a situation model. In the mind, conceptual models adapt to cognitively organized life circumstances, leading to predictions about future conditions. We reflect and predicted behavior to physiological climate. At the other hand, Senge (1990) looked at mental model as an interpretation of process and of traditional ways of thinking and behaving. According to Senge (1990), mental model connects forms of human thought to direct action based on perception, desires, incentives and previous decision-making. Mental model is important because it influences our focus and impact on what we do, but most people have not realized its effect on individual behavior. The article's next discussion will focus on four main factors that are said to influence decision making in fisheries technology usage among youth fishermen namely, experience, knowledge, belief and expertise.

\section{Experience}

Experience plays an important role in improving mental models, as it affects the attitude and actions of the person. For example, a young fisherman with extensive experience in the use of advanced fishing technologies may prefer to use new methods of catching fish instead of relying on traditional techniques. A mental model is correlated with age, knowledge, experience. Age may be the reason why a portion of Malaysian fishermen, especially young fishermen, are using modern technology in their fishing practices because the younger fishermen are mostly easy to adopt it.

Youth are often associated with their favorites and skills related to the use of ICT, and the same situation can be seen in the fisheries sector. Compared to senior fishermen who have a wide experience of using traditional methods and are very reluctant to adopt new technologies, young fishermen are seen as compatible users of fisheries technology.

\section{Knowledge}

Extensive expertise in a particular area can have a huge effect on the decision-making process of an individual. In their research, Azimi et al (2013) linked education level with technology-related decision-making processes, making it easier for those with a higher education to accept technology in their everyday routine. In a study conducted by Gutierrez and Gamboa (2010) found that the use of technology is not important for traditional basic literacy but for digital literacy. It is possible that young fishermen with knowledge of fisheries technologies can use and sustain modern ways of doing fishing activities.

Many factors are linked to this such as historical experience within the family fishing network, as well as through their mutual awareness and use of information technology as passed on to them by family members and other senior colleagues (Ota, 2006). In his viewpoint, Eraut (2000) emphasizes fishermen's need to include new ways of doing things in their fishing routine. For example, the use of advanced fishing technology, seldom required to sustain their profitability in the face of new challenges such as climate change. A significant portion of fishermen have used conventional methods of fishing and it restricts their chances to learn new things (e.g. use of technology). 


\section{Belief}

According to Eckert and Bell (2005), the mental model is an important aspect. Beliefs can be interpreted at a given time as a dispositional state of mind which has the potential of manifesting itself in actual actions (Smith, 2001). Unlike intelligence, which is based on credible data, beliefs are not generally backed by empirical proof, which leads to the likelihood that someone may wrongly believe something not supported by facts. Due to past experience, youth fishermen may assume that their current techniques are better suited to boosting profits (Abu Hassan et al. 2011).

\section{Expertise}

Expertise can be expressed by experience, a long involvement in the fisheries sector that will produce more awareness and experience that will improve the expertise of the fishermen. As a consequence of their collective experience and facts, therefore, the expert's mental model represents a more coherent structure than the novice's mental model (Toker, 2012).

Youth fishermen who have technology skills may use fishing technology because they are comfortable with it. However, the impact of the experts may be the reason why fishermen choose to choose advanced methods of fishing because it is necessary for them to learn the most appropriate form of expert to help them improve the current mental model.

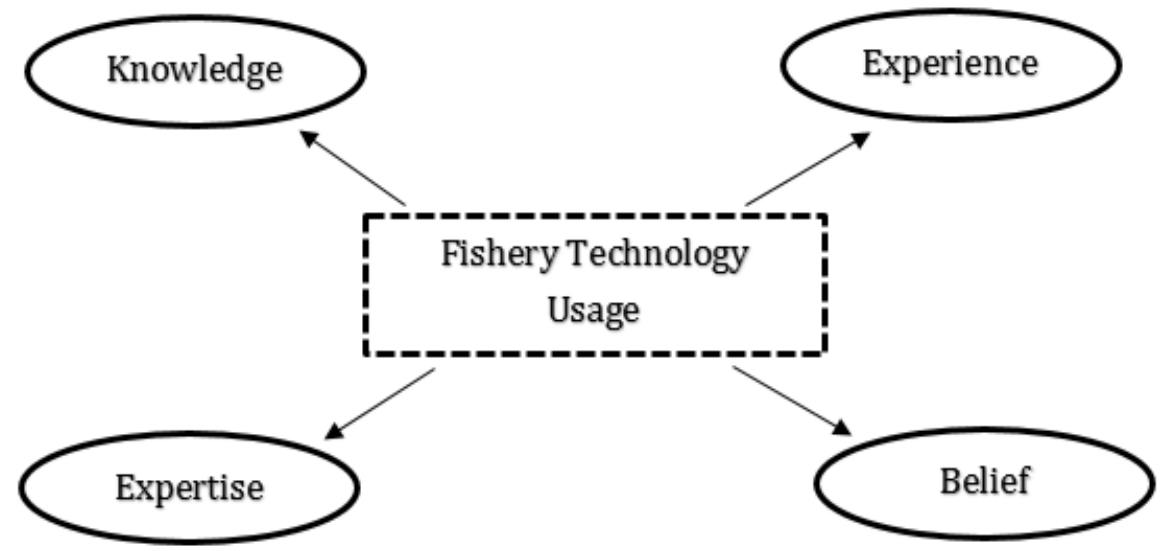

Figure 1: Factor of mental model can influence fishery technology usage

\section{Conclusion}

This paper analyzed the main mental model constructs concluded by studies of Azimi et al. (2014), Eckert and Bell (2006), and Eckert and Bell (2005). Each of these studies concluded that four (4) key domain factors in mental model are being tested in relation to the use of fishery technology among coastal youth fishermen such as awareness, experience, confidence and expertise. These four (4) factors reinforce understanding on technology adoption decision-making among young fishermen.

This awareness is hoped to assist related parties and future researchers to explore the best ways for youth fishermen in Malaysia to use fishing technologies to tackle existing poverty problems and exacerbate climate change. Mental model related to the use of technology by fishermen is still in the infancy stage and it is an opportunity for potential researchers to expand this new experience and application through new study discipline. 
INTERNATIONAL JOURNAL OF ACADEMIC RESEARCH IN BUSINESS AND SOCIAL SCIENCES

Vol. 11, No. 15, Empowering Youth and Community Wellbeing for Sustainable Development, 2021, E-ISSN: 2222-6990 @ 2020 HRMARS

\section{Acknowledgment}

The research team would like to thank Ministry of Higher Education Malaysia for providing Fundamental Research Grant Scheme for this study. (GP/2018/9624400)

\section{Refferences}

Abu Hassan, M., Shaffril, H. A. M., D’Silva, J. L., Omar, S. Z., \& Bolong, J. (2011). Fishermen and ICT: Towards creating knowledgeable fishermen in Malaysia. Australian Journal of Basic and Applied Sciences, 5, 457-469.

Azimi, H., Krauss, S. E., Shaffril, H. A. M., Suandi, T., Ismail, I. A., \& Abu Samah B. (2013). Toward understanding Malaysian fishermen's decision making on the use of fishing technology: $A$ mental model approach. International Journal of Psychology, 49 (5), 397-403.

Bolong, J., Omar, S. Z., Shaffril, H. A. M., D’Silva, J. L., \& Abu Hassan, M. (2012). Communication technologies and fishermen: Lessons learned from Langkawi Island and Kuala Besut. Science Series Data Report, 4, 2-12.

Bonabana-Wabbi, J. (2002). Assessing factors affecting adoption of agricultural technologies: The case of Integrated Pest Management (IPM) in Kumi District, Eastern Uganda. Cite seer.

Department of Fisheries Malaysia. (2010). Number of Fishermen Working on Licensed Fishing Vessels, 2010. Retrieved from:

http://www.dof.gov.my/c/document_library/get_file?uuid=3e973437-e71e

4428 b528fbb01ba60be7\& groupld=952434

Eckert, E., \& Bell, A. (2005). Retrieved from: http://www.joe.org/joe/2005june/a2.php

Eckert, E., \& Bell, A. (2006). Continuity and change: Themes of mental model development among small- Scale farmers. Journal of Extension, 44, 21-35.

FAO (1996). Technical Guidelines for Responsible Fisheries - Precautionary Approach to Capture Fisheries and Species Introductions - 2. Food and Agriculture Organization of the United Nations. Swedish National Board of Fisheries.

Ghee-Thean, L., Abd Latif, I., \& Hussein, M. A. (2012). Does technology and other determinants effect fishing efficiency? An application of stochastic frontier and data envelopment analyses on trawl fishery. Journal of Applied Science, 12(1), 48-55.

Gutierrez, L. H., \& Gamboa, L. F. (2010). Determinants of ICT usage among low-income groups in Colombia, Mexico, and Peru. The Information Society: An International Journal, 26, 346-363.

Hall, B. H., and Khan, B. (2002). Adoption of new technology. In New Economy Handbook (Hall and Khan).

Hamzah, A., Krauss, S. E., Shaffril, H. A. M., Suandi, T., Ismail, I. A., \& Abu Samah B. (2013). Toward understanding Malaysian fishermen's decision making on the use of fishing technology: A mental model approach. International Journal of Psychology, 49(5), 397-403.

Jain, R., Arora, A., \& Raju, S. (2009). A novel adoption index of selected agricultural technologies: Linkages with infrastructure and productivity. Agricultural Economics Research Review, 22(1), 109-120.

Krauss, S. E., Hamzah, A., Omar, S. Z., Suandi, T., Ismail, I. A., \& Zahari, M. Z. (2009). Preliminary investigation and interview guide development for studying how Malaysian farmers' form their mental models of farming. The Qualitative Report, 14, 245-260.

Loevinsohn, M., Sumberg, J., Diagne, A., \& Whitfield, S. (2013). Under what circumstances and conditions does adoption of technology result in increased agricultural productivity? A Systematic Review. 
Musa, A. H., Shaffril, H. A. M., D’Silva, J. L. Omar, S. Z., \& Bolong, J. (2011). Fishermen and ICT: Towards Creating Knowledgeable Fishermen in Malaysia. Australian Journal of Basic and Applied Sciences, 5(9), 457-469.

Omar, S. Z., Abu Hassan, M., Shaffril, H. A. M., Bolong, J., \& D’Silva, J. L. (2012). Factor use of ICT among fishermen. Paper presented at 9th Biannual Pacific Asian Communication Conference, Korea.

Osman, N., Omar, S. Z., Bolong, J. L., D’Silva, J. L., \& Shaffril, H. A. M. (2014). Readiness of young

Malaysian fishermen to use global positioning system within the fishing operation. Asian Social Science, 10(14), 1-7.

Ota, Y. (2006). Socialisation of fishing knowledge: The emergence and transmission of new fishing technology and marine ecological knowledge in the Republic of Palau, Western Micronesia. SPC Traditional Marine Resource Management and Knowledge Information Bulletin, 20, 24-32.

Razali, A. M., Sapuan, M. S., Ibrahim, K., Zaharim, A., \& Sopian, K. (2010). Mapping the annual extreme wind speed analysis from 12 stations in Peninsular Malaysia. ICOSSSE'10 Proceedings of the 9th WSEAS international conference on System science and simulation in engineering, 2010.

Seel, N. M. (2001). Epistemology, situated cognition, and mental models: 'like a bridge over troubled water. Instructional Science, 29, 403-427.

Senge, P. M. (1990). The fifth discipline: The art and practice of the learning organization. New York, NY: Doubleday.

Shaffril, H. A. M., Abu Samah, B., D'Silva, J. L., \& Yassin, S. M. (2013). The process of social adaptation towards climate change among Malaysian fishermen. International Journal of Climate Change Strategies and Management, 5(1), 38-53.

Shaffril, H. A. M., D’Silva, J. L., Kamaruddin, N., \& Omar, S. Z. (2015). The coastal community awareness towards the climate change in Malaysia. International Journal of Climate Change Strategies and Management, 7(4), 516-533.

Shaffril, H. A. M., Omar, S. Z., Bolong, J., \& Silva, D. J. L. (2015). Mapping the patterns of mobile phone usage among fishermen in Malaysia. Information Technology for Development, 21 (4), 543-554.

Shaffril, H. A. M., Abu Samah, A., \& D'Silva, J. L. (2017). Adapting towards climate change impacts: Strategies for small-scale fishermen in Malaysia. Marine Policy 81, 196-201.

Smith, A. (2001). Perception and belief. Philosophy and Phenomenological Research, 2, 294-309.

Subramaniam, K., Kwok, L. L., \& Wan Azli, W. H. (2010,). Extreme rainfall changes over Malaysia. Observation and projection. Paper presented at National Symposium on Climate Change Adaptation, November 16-17. Putrajaya, Malaysia.

Suhaila, J., Deni, S. M., Wan, Z. W. Z., Jemain, A. A. (2010). Spatial patterns and trends of daily rainfall regime in Peninsular Malaysia during the southwest and northeast monsoon: 1975-

2004. Meteorology and Atmospheric Physics; 110: 1-18.

Tanggang, F. (2007). "Climate change and global warming: Malaysia perspective and challenges", paper presented at UKM Public Speech, Anuar Mahmud Hall, and University Kebangsaan Malaysia.

Toker, S. (2012). The mental model comparison of expert and novice performance improvement practitioners. Wayne State University Dissertations.

Azli, W. H. (2010), "Influence of climate change on Malaysia weather pattern", paper presented at Malaysia Green Forum 2010 (MGF2010), 26-27 April, Putrajaya.

Whitmarsh, D. (1990). Technological change and marine fisheries development. Marine Policy, 14, 15-22. 